\title{
Synthesis and characterization of $\mathrm{NiO}$ doped beta- $\mathrm{Al}_{2} \mathrm{O}_{3}$ solid electrolyte
}

\author{
Chengfei Zhu*, Yongfei Hong, Pan Huang \\ College of Materials Science and Engineering, Nanjing Tech University, \\ 5 Xinmofan Road, Nanjing, Jiangsu 210009, PR China
}

\begin{abstract}
The beta- $\mathrm{Al}_{2} \mathrm{O}_{3}$ solid electrolyte with $\mathrm{NiO}$ doped and $\mathrm{Li}_{2} \mathrm{O}$ stabilized is synthesized via the solid state reaction method, which is starting with $\alpha-\mathrm{Al}_{2} \mathrm{O}_{3}$, $\mathrm{Li}_{2} \mathrm{CO}_{3}, \mathrm{Na}_{2} \mathrm{C}_{2} \mathrm{O}_{4}$ and $\mathrm{Ni}\left(\mathrm{NO}_{3}\right)_{2} \cdot 6 \mathrm{H}_{2} \mathrm{O}$ as the raw materials. Effects of the $\mathrm{NiO}$ content on the mechanical and electrical performances are studied by means of thermogravimetry/differential scanning calorimetry (TG/DSC), X-ray diffraction (XRD) and scanning electron microscopy (SEM). Meanwhile, the relative density, the bending strength and the electrical properties of the prepared samples are also measured in this paper. The beta- $\mathrm{Al}_{2} \mathrm{O}_{3}$ solid electrolyte with the appropriate amount of $\mathrm{NiO}$ has a higher $\beta^{\prime \prime}-\mathrm{Al}_{2} \mathrm{O}_{3}$ phase content and uniform microstructure with dense and plump grains. However, the excess $\mathrm{NiO}$ doping can lead the grain to molten state and make the pores become larger. It deteriorates the ionic conductivity. When the $\mathrm{NiO}$ content of the beta- $\mathrm{Al}_{2} \mathrm{O}_{3}$ solid electrolyte is $0.25 \mathrm{wt} \%$, the $\beta "-\mathrm{Al}_{2} \mathrm{O}_{3}$ phase
\end{abstract}

* Corresponding author. Tel:+86 2583172117 Fax:+86 2583172118

E-mail address: zhucf@njtech.edu.cn(C.-F. Zhu) 
content is $98.91 \%$, the microstructure is uniform and compact, the relative density is $98.73 \%$ of theoretical density, the bending strength is up to $296 \mathrm{MPa}$ and the ionic conductivity can reach $0.066 \mathrm{~S} \mathrm{~cm}^{-1}$ at $350{ }^{\circ} \mathrm{C}$.

Keywords: Sodium-sulfur battery; beta- $\mathrm{Al}_{2} \mathrm{O}_{3}$ solid electrolyte; $\mathrm{NiO}$ doping; bending strength

\section{Introduction}

As a new energy storage battery, sodium sulfur batteries have many advantages, such as high specific energy, high charge and discharge power, long cycle life, low cost, no pollution and so on [1-5]. It takes beta- $\mathrm{Al}_{2} \mathrm{O}_{3}$ as an electrolyte and separator, sodium polysulfide and sodium metal as the positive electrode and the negative electrode in the sodium sulfur batteries, respectively. The operating temperature of sodium sulfur battery is $300-350{ }^{\circ} \mathrm{C}$, so the requirements on the beta- $\mathrm{Al}_{2} \mathrm{O}_{3}$ solid electrolyte are very strict. More and more people pay attention to studying the preparation and performance of the beta- $\mathrm{Al}_{2} \mathrm{O}_{3}$ solid electrolyte in the sodium-sulfur batteries.

In order to improve the ionic conductivity and mechanical property of the Nabeta- $\mathrm{Al}_{2} \mathrm{O}_{3}$ solid electrolyte, some elements were doped in the matrix material. For example, it could improve the conductivity by adding an appropriate amount of $\mathrm{Li}_{2} \mathrm{O}$ or $\mathrm{MgO}$ to the beta- $\mathrm{Al}_{2} \mathrm{O}_{3}$ solid electrolyte [6-10]. But it decreased the mechanical properties at the same time. Shan et al. [11] pointed out that the bending strength of the beta- $\mathrm{Al}_{2} \mathrm{O}_{3}$ solid electrolyte was up to $180 \mathrm{MPa}$ by using $\mathrm{TiO}_{2}$ doping. Sheng et al. 
$[12,13]$ found the flexural strength increased with the increasing of the content of $\mathrm{ZrO}_{2}$. Yang et al. [14] studied the beta- $\mathrm{Al}_{2} \mathrm{O}_{3}$ solid electrolyte by adding $\mathrm{ZrO}_{2}$ to increase the mechanical properties and adding $\mathrm{TiO}_{2}$ to enhance the conductivity. Xu et al. [15] found that a small amount of $\mathrm{Y}_{2} \mathrm{O}_{3}$ could improve the mechanical strength and electrical conductivity by using the double zeta process to prepare the beta- $\mathrm{Al}_{2} \mathrm{O}_{3}$ solid electrolyte.

However, the $\mathrm{Ni}$ doping could increase the density, the superconducting properties and the toughness of Bi-2212 superconducting ceramics [16]. Ma [17] found that $\mathrm{NiO}$ doping could improve sintering properties and electrical conductivity of 4YSZ. Xiao et al. [18], who doped with different concentrations of $\mathrm{Ni}$ in $\mathrm{Bi}_{4} \mathrm{NdTi}_{3} \mathrm{FeO}_{15}$ ceramics, found that a small amount of Ni doping didn't change the structure of ceramic but improved the properties. Das et al. [19] pointed out that the magnetic of BTO ceramics was also enhanced with the increasing of the $\mathrm{NiO}$ concentration. So the $\mathrm{NiO}$ doping in ceramics could not only improve the ceramic sintering activity, but also enhance the conductivity and mechanical properties. But there are no reports about the effect of $\mathrm{NiO}$ doping on the performance of the beta- $\mathrm{Al}_{2} \mathrm{O}_{3}$ solid electrolyte currently.

The beta- $\mathrm{Al}_{2} \mathrm{O}_{3}$ solid electrolyte is often synthesized by solid state reaction method [20-23] or novel soft-chemical methods such as sol-gel processing [10,11], alkoxide hydrolysis [24,25], solution combustion technique [26], co-precipitation [27] and electrophoretic deposition [28]. The solid state reaction method is both economic and easy to carry out, so it is used in this article. 
In this paper, we investigate the effects of $\mathrm{NiO}$ doping on the mechanical and electrical properties of the beta- $\mathrm{Al}_{2} \mathrm{O}_{3}$ solid electrolyte by thermogravimetry/ differential scanning calorimetry (TG/DSC), X-ray diffraction (XRD), scanning electron microscopy (SEM). The relative density, mechanical strength and ionic conductivity are also measured and discussed in detail.

\section{Experimental}

\subsection{Synthesis}

The beta- $\mathrm{Al}_{2} \mathrm{O}_{3}$ solid electrolytes with different contents of $\mathrm{NiO}$ were synthesized via the solid state reaction method using high-purity $\alpha-\mathrm{Al}_{2} \mathrm{O}_{3}$ (model VK-L30), $\mathrm{Na}_{2} \mathrm{C}_{2} \mathrm{O}_{4}(\mathrm{AR})$, and $\mathrm{Li}_{2} \mathrm{CO}_{3}(\mathrm{AR})$. The stabilizer was $\mathrm{Li}_{2} \mathrm{O}$. Then the mixed powders were divided into 9 groups and added $\mathrm{NiO}$ with $0 \mathrm{wt} \%, 0.01 \mathrm{wt} \%, 0.05 \mathrm{wt} \%$, $0.1 \mathrm{wt} \%, 0.15 \mathrm{wt} \%, 0.25 \mathrm{wt} \%, 0.50 \mathrm{wt} \%, 1 \mathrm{wt} \%, 1.5 \mathrm{wt} \%$ ratios, respectively. The 9 groups were ball-milled in an absolute alcohol medium for $10 \mathrm{~h}$ with the fixed rotation speed of $400 \mathrm{rpm}$, dried at $80{ }^{\circ} \mathrm{C}$, and then calcined at $1250{ }^{\circ} \mathrm{C}$ for $2 \mathrm{~h}$. These products were the precursor powders of beta- $\mathrm{Al}_{2} \mathrm{O}_{3}$. The precursor powders were ball-milled with ethanol for another $10 \mathrm{~h}$, then dried, and mixed with an appropriate amount of $5 \mathrm{wt} \%$ polyvinyl alcohols. In order to prepare the ceramic samples, the powder was pressed into two sizes: $3 \mathrm{~mm}(\mathrm{D}) \times 4 \mathrm{~mm}(\mathrm{~W}) \times 40 \mathrm{~mm}(\mathrm{~L})$ and $\Phi 16$ $\mathrm{mm} \times 2 \mathrm{~mm}(\mathrm{D})$. The green ceramics were covered with the precursor powders and fired at $1600{ }^{\circ} \mathrm{C}$ for $10 \mathrm{~min}$. In order to accelerate the formation of $\beta$ "- $\mathrm{Al}_{2} \mathrm{O}_{3}, 2 \mathrm{~h}$ holding time at $1450{ }^{\circ} \mathrm{C}$ in the cooling process was added. 


\subsection{Characterization}

The thermal stabilities of the powders were analyzed by using a thermo gravimetric analyzer (TG, STA449C, Netzsch, Germany) and a differential scanning calorimeter (DSC, 204/1/F, Netzsch, Germany) from room temperature $\left(20^{\circ} \mathrm{C}\right)$ to $1400{ }^{\circ} \mathrm{C}$ in air atmosphere, with a heating rate of $10{ }^{\circ} \mathrm{C} \mathrm{min}^{-1}$.

To determine the phase composition of the precursor powders and sinters, X-ray diffractometer (XRD, Rigaku, Japan) analysis was carried out for all the samples with $\mathrm{Cu} \mathrm{K} \alpha$ radiation $(\lambda=1.5406 \AA)$. The scanning speed was $10^{\circ} \mathrm{min}^{-1}$ in the $2 \theta$ ranges from $5^{\circ}$ to $80^{\circ}$. The relative ratio of $\mathrm{Na}-\beta-\mathrm{Al}_{2} \mathrm{O}_{3}$ and $\mathrm{Na}-\beta$ " $-\mathrm{Al}_{2} \mathrm{O}_{3}$ were quantitative calculated by the following equation [29].

$$
f\left(\beta^{\prime \prime}\right) \%=100-f(\beta) \%-\frac{I_{\beta}}{I_{\beta}+0.85 I_{\beta^{\prime \prime}}} \times 100 \%
$$

Where $I_{\beta}$ and $I_{\beta}{ }^{\prime \prime}$ were the peak intensities at $44.50^{\circ}$ and $45.90^{\circ}$, respectively. $f\left(\beta^{\prime \prime}\right) \%$ and $f(\beta) \%$ were the relative ratio of $\mathrm{Na}-\beta "-\mathrm{Al}_{2} \mathrm{O}_{3}$ and $\mathrm{Na}-\beta-\mathrm{Al}_{2} \mathrm{O}_{3}$, respectively.

The microstructure of the sinters was observed by a scanning electron microscope (SEM, JEOL, JSM5900). The discs were cut into small pieces, polished, and etched by the boiling phosphoric acid for $45 \mathrm{~s}$. The cross sections were examined.

The bending strength measurements were performed in three point bending (span $30 \mathrm{~mm}$ ) on rectangular sintered specimens with cross-section of $3 \mathrm{~mm} \times 4 \mathrm{~mm}$. They were determined on the Electronic Universal Testing Machine (CMT 6203) at room temperature $\left(20^{\circ} \mathrm{C}\right)$ with $0.5 \mathrm{~mm} \mathrm{~min}^{-1}$ indenter loading.

The density of the sintered samples was measured using Archimedean principle 
under the room temperature $\left(20{ }^{\circ} \mathrm{C}\right)$. The measured density $\mathrm{D}_{\mathrm{b}}\left(\mathrm{g} \mathrm{cm}^{-3}\right)$ calculated by $\mathrm{Eq}(2)$.

$$
\mathrm{D}_{\mathrm{b}}=\frac{\mathrm{m}_{1} \cdot \mathrm{D}_{1}}{\mathrm{~m}_{3}-\mathrm{m}_{2}} \times 100 \%
$$

Where $\mathrm{m}_{1}(\mathrm{~g})$ was the weigh of the dry samples, $\mathrm{m}_{2}(\mathrm{~g})$ was the weigh of the saturated sample suspended in the anhydrous ethanol, $m_{3}(\mathrm{~g})$ was the weigh of the saturated sample in the air, $\mathrm{D}_{1}$ was the density of the anhydrous ethanol at $20^{\circ} \mathrm{C}$ $\left(0.7903 \mathrm{~g} \mathrm{~cm}^{-3}\right)$.

The ionic conductivity of the sintered samples was examined at $50-400^{\circ} \mathrm{C}$ in the air using a frequency response analyzer (Solartron 1260) and an electrochemical interface (SI 1287). The frequency range applied was from $0.1 \mathrm{~Hz}$ to $10^{7} \mathrm{~Hz}$ with signal amplitude of $20 \mathrm{mV}$. The sintered specimens for ionic conductivity measurements were disc-shaped with the diameter of $16 \mathrm{~mm}$ diameter and thickness of $1 \mathrm{~mm}$. Both faces of the pellets were carefully polished, covered with silver paste and fired afterwards to obtain silver electrode as the current collector. Then Platinum lead was well attached to the silver electrode surfaces, and impedance measurements were carried out in these two-electrode symmetric cells. The impedance spectra were analyzed by the equivalent circuit of the program Zview.

\section{Results and discussion}

\subsection{Thermogravimetric Analysis}

Fig.1 shows the TG and DSC curves of the raw material containing $0.15 \mathrm{wt} \%$ NiO. The mass loss is $5.86 \mathrm{wt} \%$ during $300{ }^{\circ} \mathrm{C}$ and $500{ }^{\circ} \mathrm{C}$, and an exothermic peak is 
existed near $430{ }^{\circ} \mathrm{C}$. It should be present in the decomposition reaction of $\mathrm{Na}_{2} \mathrm{C}_{2} \mathrm{O}_{4}$ and $\mathrm{Ni}\left(\mathrm{NO}_{3}\right)_{2} \cdot 6 \mathrm{H}_{2} \mathrm{O}$. The mass loss is $5.90 \mathrm{wt} \%$ between $500{ }^{\circ} \mathrm{C}$ and $800^{\circ} \mathrm{C}$, while an endothermic peak is existed near $768{ }^{\circ} \mathrm{C}$ in the DSC curve. It should be the melting and decomposition of $\mathrm{Na}_{2} \mathrm{CO}_{3}$ and $\mathrm{Li}_{2} \mathrm{CO}_{3}$. During $900{ }^{\circ} \mathrm{C}$ and $1050{ }^{\circ} \mathrm{C}$, some waves are existed in the DSC curve, but the mass is almost unchanged. It should be the phase transition process from $\beta$ phase to $\beta "$ phase [30]. The DSC curve trends to the balance at about $1250{ }^{\circ} \mathrm{C}$, it can illustrate that the phase transition to the balance. Then it combines with the literatures $[6,8]$. So the sintering temperature of the precursor powder is at $1250{ }^{\circ} \mathrm{C}$ in this paper.

\subsection{XRD analysis of precursor powder}

Fig.2 shows the XRD patterns of the precursor powders doped with different amounts of $\mathrm{NiO}$. The phase of $\alpha-\mathrm{Al}_{2} \mathrm{O}_{3}$ exists in the samples with the $\mathrm{NiO}$ content of 0wt $\%$ and $0.01 \mathrm{wt} \%$. When the $\mathrm{NiO}$ content is above $0.05 \mathrm{wt} \%$, the XRD patterns is presented that all of the samples almost comprise both $\beta$ - and $\beta^{\prime \prime}-\mathrm{Al}_{2} \mathrm{O}_{3}$ phases. It can improve the sintering activity of ceramics by adding $\mathrm{NiO}$ [17]. According to the Eq. (1), the ratios of the $\beta^{\prime \prime}-\mathrm{Al}_{2} \mathrm{O}_{3}$ phase are calculated and listed in Table 1 . The $\beta^{\prime \prime}-\mathrm{Al}_{2} \mathrm{O}_{3}$ phase content reaches a maximum $(82.54 \%)$ when the content of $\mathrm{NiO}$ is $0.25 \mathrm{wt} \%$. It is indicated that an appropriate amount of $\mathrm{NiO}$ doping can promote $\beta-\mathrm{Al}_{2} \mathrm{O}_{3}$ transformation at lower temperature and produce more $\beta "-\mathrm{Al}_{2} \mathrm{O}_{3}$.

\subsection{Analysis of the sinters}




\subsubsection{Phase analysis}

The XRD patterns of the beta-alumina sinters with different $\mathrm{NiO}$ contents are shown in Fig.3. All the samples are composed of the $\beta$ - and $\beta "-\mathrm{Al}_{2} \mathrm{O}_{3}$ phases. The $\beta^{\prime \prime}-\mathrm{Al}_{2} \mathrm{O}_{3}$ phase contents in sinters are calculated according to Eq. (1) and summarized in Table 2.

According to Table 2, the $\beta "-\mathrm{Al}_{2} \mathrm{O}_{3}$ phase contents remain above $95 \%$ with the $\mathrm{NiO}$ amount from $0.05 \mathrm{wt} \%$ to $1.5 \mathrm{wt} \%$. The $\beta^{\prime \prime}-\mathrm{Al}_{2} \mathrm{O}_{3}$ phase content is the maximum $(98.91 \%)$ when the content of $\mathrm{NiO}$ is $0.25 \mathrm{wt} \%$ in all the samples. It can be observed that the $\mathrm{NiO}$ doping improves the stability of $\beta "-\mathrm{Al}_{2} \mathrm{O}_{3}$ effectively at a high temperature. The radius of element $\mathrm{Ni}$ is $0.069 \mathrm{~nm}$. According to Boilot and Thery's theory [31], when the radius of divalent metal ions is under $0.097 \mathrm{~nm}$, the divalent metal ions are able to enter the spinel block to stabilize the $\beta "-\mathrm{Al}_{2} \mathrm{O}_{3}$ structure. With the increasing of $\mathrm{NiO}$ content, the $\beta^{\prime \prime}-\mathrm{Al}_{2} \mathrm{O}_{3}$ phase content is enhanced. When the morphology of the samples appears molten state, the $\beta "-\mathrm{Al}_{2} \mathrm{O}_{3}$ phase content is decreased. It can be inferred that the molten state prevents the $\beta "-\mathrm{Al}_{2} \mathrm{O}_{3}$ phases from producing.

\subsubsection{Microstructure analysis}

Fig.4 is the cross section micrograph of the sinters with various amounts of $\mathrm{NiO}$. The undoped sample possesses loose structure, nonuniform particles and many pores in Fig.4a. After being doped by $\mathrm{NiO}$, the particles of the samples become more homogeneous and denser. It can refine grains and strengthen the grain boundaries by $\mathrm{NiO}$ doping [32]. Although the samples containing $0.01-0.25 \mathrm{wt} \% \mathrm{NiO}$ are denser, 
there are still some areas nonuniform and some large particles. When the amount of $\mathrm{NiO}$ is $0.01 \mathrm{wt} \%$, the microstructure is mainly the cone-like and short rod-like grains. When the amount of $\mathrm{NiO}$ is $0.15 \mathrm{wt} \%$, the grains of the sinters are obviously refined, and the size of them is more uniform, but it also exists some small pores. When the amount of $\mathrm{NiO}$ is $0.25 \mathrm{wt} \%$, the microstructure begins to appear the molten state, but it isn't very obvious. The size of the grains is relatively uniform. While the amount of $\mathrm{NiO}$ is more than $0.25 \mathrm{wt} \%$, the microstructure of the samples appears the obvious molten state, so the size of their grains becomes irregular and the pores become larger and larger. At the same time, their grain boundaries become less and less clear. According to the analysis of the XRD patterns and the literature [17], it can improve the sintering activity and increase the $\beta "-\mathrm{Al}_{2} \mathrm{O}_{3}$ phase content of the beta- $\mathrm{Al}_{2} \mathrm{O}_{3}$ solid electrolytes by adding $\mathrm{NiO}$. It indicates that the excess $\mathrm{NiO}$ content reduce the sintering temperature of the sinters, and make the microstructure more easy to appear the molten state. But the grains are too massive. It would significantly deteriorate the bending strength and ionic conductivity of the material [11].

\subsubsection{Volume density analysis}

Fig.5 displays the measured density and the relative density of all the sinters, which calculated according to the Eq. (2). With the increasing of $\mathrm{NiO}$ content, the densities become enlargement first and then decreased. The relative density of the sinter can reach $98.73 \%\left(3.1987 \mathrm{~g} \mathrm{~cm}^{-3}\right)$ when the amount of $\mathrm{NiO}$ is $0.25 \mathrm{wt} \%$. The changing process of the density is consistent with the microstructure analysis. The denser the particles are, the larger the densities are. 


\subsubsection{Bending strength analysis}

The bending strengths of the beta- $\mathrm{Al}_{2} \mathrm{O}_{3}$ solid electrolytes are also shown in Table 2. The bending strength of the non-doping sample is only about $194 \mathrm{MPa}$. It enhances with the increasing of $\mathrm{NiO}$ contents $(0.01-0.25 \mathrm{wt} \%)$. The maximum bending strength is $296 \mathrm{MPa}$ when the $\mathrm{NiO}$ content is $0.25 \mathrm{wt} \%$. Because a small amount of the molten state can make the microstructure have no obvious pores, and increase the binding force between the particles (Fig.4f). When the NiO amount exceeds $0.25 \mathrm{wt} \%$, the bending strength decreased. This can be attributed to the large size pores and the irregular size of the grains according to Fig.4g-i. Because adding NiO can improve the sintering activity, it leads the grain to the molten state and makes the pores become larger, then destroys the binding force between the particles and reduces the bending strength of the sinters.

\subsubsection{Ionic conductivity analysis}

Fig.6 is the AC impedance spectra of the samples with different content of $\mathrm{NiO}$ at $350^{\circ} \mathrm{C}$. There are a small semicircle and a tail in these impedance spectra. Fig.7 shows the equivalent circuit used to represent the beta- $\mathrm{Al}_{2} \mathrm{O}_{3}$ solid electrolytes in contact with silver electrode. The ionic conductivities of the sintered samples with various amounts of $\mathrm{NiO}$ at $350{ }^{\circ} \mathrm{C}$ are shown in Table 2 . Due to its loose structure, the ionic conductivity of the undoped sample is only $0.015 \mathrm{~S} \mathrm{~cm}^{-1}$. With the increase of $\mathrm{NiO}$ doping amounts, the ionic conductivity enhances. The ionic conductivity reaches to the maximum $\left(0.066 \mathrm{~S} \mathrm{~cm}^{-1}\right)$ when the $\mathrm{NiO}$ content is $0.25 \mathrm{wt} \%$. While the content of $\mathrm{NiO}$ exceeds $0.25 \mathrm{wt} \%$, the ionic conductivity decreases quickly. Because the 
excess of $\mathrm{NiO}$ improves the sintering activity of the sinters, it makes the grains appear the molten state and the grain boundaries become blurred. At the same time the particles are not uniform and dense. They lead the pores between the particles to become large and it enhances the grain boundary resistance of sinters. So the ionic conductivity reduces when the increase of $\mathrm{NiO}$ content.

It is found that the plots of $\ln (\sigma \mathrm{T})$ verses $\left(1000 \mathrm{~T}^{-1}\right)$ are linear over the temperature range. Fig. 8 shows the Arrhenius plot of resistivity data for the sintered samples with various amounts of $\mathrm{NiO}$. The relationship conforms to Arrhenius equation.

$$
\sigma \mathrm{T}=\mathrm{A} \exp (-\mathrm{Ea} / \mathrm{RT})
$$

Where $\mathrm{R}$ is the gas constant, $\mathrm{T}$ is the absolute temperature.

The corresponding values for Ea (activation energy) of all the samples are listed in Table 2. The low Ea indicates that the Na ions migrate easily. The lowest Ea of all the samples is $0.166 \mathrm{eV}$ when the $\mathrm{NiO}$ content is $0.25 \mathrm{wt} \%$.

\section{Conclusions}

In the $\mathrm{Na}_{2} \mathrm{O}-\mathrm{Al}_{2} \mathrm{O}_{3}-\mathrm{Li}_{2} \mathrm{O}-\mathrm{NiO}$ system, the $\beta^{\prime \prime}-\mathrm{Al}_{2} \mathrm{O}_{3}$ phase is formed at the low temperature of $1250{ }^{\circ} \mathrm{C}$. All the $\beta^{\prime \prime}-\mathrm{Al}_{2} \mathrm{O}_{3}$ phase contents of $0.05-1.5 \mathrm{wt} \% \mathrm{NiO}$ doping samples are above $94 \%$. The samples with $0.05-0.25 \mathrm{wt} \%$ doping possess uniform microstructure with dense and plump grains. And it shows a high density and bending strength. However, the excess $\mathrm{NiO}$ doping would lead the grain to molten state and make the pores become larger. It deteriorates the ionic conductivity. When the content 
of $\mathrm{NiO}$ of beta- $\mathrm{Al}_{2} \mathrm{O}_{3}$ solid electrolyte is $0.25 \mathrm{wt} \%$, the $\beta "-\mathrm{Al}_{2} \mathrm{O}_{3}$ phase content is $98.91 \%$, the microstructure is uniform and compact, the relative density is $98.73 \%$ of theoretical density, the bending strength is up to $296 \mathrm{MPa}$ and the ionic conductivity can reach $0.066 \mathrm{~S} \mathrm{~cm}^{-1}$ at $350^{\circ} \mathrm{C}$.

\section{Acknowledgements}

The authors appreciate the financial supports from the National Natural Science Foundation of China (Grant No.21203095), the National Science Foundation for Post-doctoral Scientists of China (Grant No. 2012M511261), the Jiangsu National Synergetic Innovation Center for Advanced Materials (SICAM) and the Priority Academic Program Development of Jiangsu Higher Education Institutions.

\section{References:}

[1] E.C. Kluiters, D. Schmal, W.R. Veen, KJCM Posthumus, Testing of a sodium/nickel chloride (ZEBRA) battery for electric propulsion of ships and vehicles, J. Power Sources 80 (1999) 261-264.

[2] C.W. Park, H.S. Ryu, K.W. Kim, J.H. Ahn, J.Y. Lee, H.J. Ahn, Discharge properties of all-solid sodium-sulfur battery using poly (ethylene oxide) electrolyte, J. Power Sources 165 (2007) 450-454.

[3] J.L. Wang, J. Yang, Y. Nuli, R. Holze, Room temperature Na/S batteries with sulfur composite cathode materials, Electrochem. Commun. 9 (2007) 31-34.

[4] C.W. Sun, Developing trends of Sodium/Sulfur and Sodium/Metal Chloride 
batteries( I ), Battery Bimon. 23 (1993) 75-78.

[5] C.W. Sun, Developing trends of Sodium/Sulfur and Sodium/Metal Chloride batteries( II ), Battery Bimon. 23 (1993) 138-140.

[6] C.F. Zhu, J.H. Xue, Structure and properties relationships of beta- $\mathrm{Al}_{2} \mathrm{O}_{3}$ electrolyte materials, J. Alloys Compd. 517 (2012) 182-185.

[7] J.H. Park, K.H. Kim, S.K. Lim, Influence of stabilizers on Na-beta"- $\mathrm{Al}_{2} \mathrm{O}_{3}$ phase formation in $\mathrm{Li}_{2} \mathrm{O}(\mathrm{MgO})-\mathrm{Na}_{2} \mathrm{O}-\mathrm{Al}_{2} \mathrm{O}_{3}$ ternary systems, J. Mater. Sci. 23 (1998) $5671-5675$.

[8] C.F. Zhu, G.H. Ji, J.H. Xue, Influence of stabilizers on the performance of Beta- $\mathrm{Al}_{2} \mathrm{O}_{3}$ solid electrolyte, Rare Metal Mat. Eng. 43 (2014) 2535-2540.

[9] T.C. Girija, A.V. Virkar, Low temperature electrochemical cells with sodium $\beta "$-alumina solid electrolyte(BASE), J. Power Sources 180 (2008) 653-656.

[10] G.X. Zhang, Z.Y. Wen, X.W. Wu, J.C. Zhang, G.Q. Ma, J. Jin, Sol-gel synthesis of $\mathrm{Mg}^{2+}$ stabilized $\mathrm{Na}-\beta " / \beta-\mathrm{Al}_{2} \mathrm{O}_{3}$ solid electrolyte for sodium anode battery, J. Alloys Compd. 613 (2014) 80-86.

[11] S.J. Shan, L.P. Yang, X.M. Liu, X.L. Wei, H. Yang, X.D. Shen, Preparation and characterization of $\mathrm{TiO}_{2}$ doped and $\mathrm{MgO}$ stabilized $\mathrm{Na}-\beta "-\mathrm{Al}_{2} \mathrm{O}_{3}$ electrolyte via a citrate sol-gel method, J. Alloys Compd. 563 (2013) 176-179.

[12] Y. Sheng, P.S. Nicholson, Microstructural development of a $\mathrm{ZrO}_{2}-\mathrm{Na}$-beta"$\mathrm{Al}_{2} \mathrm{O}_{3}$ composite, J. Mater. Sci. 23 (1988) 982-986.

[13] Y. Sheng, P. Sarkar, P.S. Nicholoson, The mechanical and electrical-properties of ZrO2-Na-beta"- $\mathrm{Al}_{2} \mathrm{O}_{3}$ composite, J. Mater. Sci. 23 (1988) 958-967. 
[14] L.P. Yang, S.J. Shan, X.L. Wei, X.M. Liu, H. Yang, X.D. Shen, The mechanical and electrical properties of $\mathrm{ZrO}_{2}-\mathrm{TiO}_{2}-\mathrm{Na}-\beta / \beta^{\prime \prime}$-alumina composite electrolyte synthesized via a citrate sol-gel method, Ceram. Int. 40 (2014) 9055-9060.

[15] D. Xu, H.Y. Jiang, M. Li, O. Hai, Y. Zhang, Synthesis and characterization of $\mathrm{Y}_{2} \mathrm{O}_{3}$ doped Na- $\beta$ "- $\mathrm{Al}_{2} \mathrm{O}_{3}$ solid electrolyte by double zeta process, Ceram. Int. 41 (2015) 5355-5361.

[16] N. Wang, L.X. Fu, J. Zhang, Effect of Ni-doping on the framework structure of mesoporous silica, Fine Chem. 23 (2006) 452-455,468.

[17] X.L. Ma, Effect of NiO doping on 4YSZ conductivity properties, China's Ceram. 47 (2011) 19-21.

[18] J. Xiao, H.F. Zhang, Y. Xue, Z.W. Lu, X.Q. Chen, P. Su, F.J. Yang, X.B. Zeng, The influence of Ni-doping concentration on multiferroic behaviors in $\mathrm{Bi}_{4} \mathrm{NdTi}_{3} \mathrm{FeO}_{15}$ ceramics, Ceram. Int. 41 (2015) 1087-1092.

[19] S.K. Das, R.N. Mishra, B.K. Roul, Magnetic and ferroelectric properties of Ni doped $\mathrm{BaTiO}_{3}$, Solid State Commun. 191 (2014) 19-24.

[20] J.D. Hodge, Powder processing and crystallization of beta-aluminas and beta"-aluminas, Am. Ceram. Soc. Bull. 62 (1983) 244-248.

[21] K.M. Lee, S.T. Lee, D.H. Lee, S.M. Lee, S.L. Lim, Phase formation of $\mathrm{Na}^{+}$-beta-aluminas synthesized by double zeta process, J. Ind.and Eng.Chem.19 (2013) $829-834$

[22] X.C. Lu, G.S. Li, J.Y. Kim, K.D. Meinhardt, V.L. Sprenkle, Advanced materials for sodium-beta alumina batteries: status, challenges and perspectives, J. Power 
Sources 295 (2015) 167-174.

[23] X.L. Wei, Y. Cao, L. Lu, H. Yang, X.D. Shen, Synthesis and characterization of titanium doped sodium beta"-alumina, J. Alloys Comp. 509 (2011) 6222-6226.

[24] W. Zhou, Z.P. Shao, W.Q. Jin, Synthesis of nanocrystalline conducting composite oxides based on a non-ion selective combined complexing process for functional applications, J. Alloys Comp. 426 (2006) 368-374.

[25] V. Jayaraman, T. Gnanasekaran, G. Periaswami, Low-temperature synthesis of $\beta$-aluminas by a sol-gel technique, Mater. Lett. 30 (1997) 157-162

[26] T. Mathews, Solution combustion synthesis of magnesium compensated sodium-beta-aluminas, Mater. Sci. Eng. B 78 (2000) 39-43.

[27] H.C. Park, Y.B. Lee, S.G. Lee, C.H. Lee, J.K. Kim, S.S. Hong, S.S. Park, Synthesis of beta-alumina powders by microwave heating from solution-derived precipitates, Ceram. Int. 31 (2005) 293-296.

[28] X.L. Wei, Y. Xia, X.M. Liu, H. Yang, X.D. Shen, Preparation of sodium beta"-alumina electrolyte thin film by electrophoretic deposition using Taguchi experimental design approach, Electrochim. Acta 136 (2014) 250-256.

[29] A. Pekarsky, P.S. Nicholson, The relative stability of spray-frozen/freeze-dried $\beta^{\prime \prime}-\mathrm{Al}_{2} \mathrm{O}_{3}$ powders, Mat. Res. Bull. 15 (1980) 1517-1524.

[30] Z.Y. Wen, Y.Y. Hu, X.W. Wu, J.D. Hang, Z.H. Gu, Main challenges for high performance NAS battery: materials and interfaces, Adv. Funct. Mater. 23 (2013) 1005-1018.

[31] J.P. Boilot, J. Thery, Influence De L'addition D'ions Etrangers Sur La Stabilite 
Relative Et La Conductivite Electrique Des Phases De Type Alumine $\beta$ et $\beta^{\prime \prime}$, Mater. Res. Bull. 11 (1976) 407-413.

[32] M.X. Jing, X.Q. Shen, D.H. Li, W.X. Li, Effects of coexistence of Ni and $\mathrm{ZrO}_{2}$ inclusions on microstructure and properties of $\mathrm{Al}_{2} \mathrm{O}_{3}$ ceramics, J. Chin. Ceram. Soc. 35 (2007) 35-40.

\section{Captions list:}

Table 1 - The $\beta$ " phase content in precursor powders with different amounts of $\mathrm{NiO}$ doping.

Table 2 - Some calculated parameters and measured properties of the sinters with different amounts of $\mathrm{NiO}$ doping

Fig. 1 TG and DSC curves of the specimen with $0.15 \mathrm{wt} \% \mathrm{NiO}$

Fig.2 XRD spectra of precursor powders with different amounts of $\mathrm{NiO}$ doping

Fig. 3 XRD spectra of the sinters with different amounts of NiO doping

Fig.4 The cross section micrograph of the sinters with different amounts of $\mathrm{NiO}$ doping

Fig.5 The measured and relative densities of the sinters with different amounts of $\mathrm{NiO}$ doping

Fig.6 The impedance spectra of the sinters with different amounts of $\mathrm{NiO}$ doping at $350^{\circ} \mathrm{C}$

Fig.7 Equivalent circuits at different $\mathrm{NiO}$ contents 
Fig.8 Arrhenius plot of resistivity data for the sinters with different amounts of $\mathrm{NiO}$ doping 


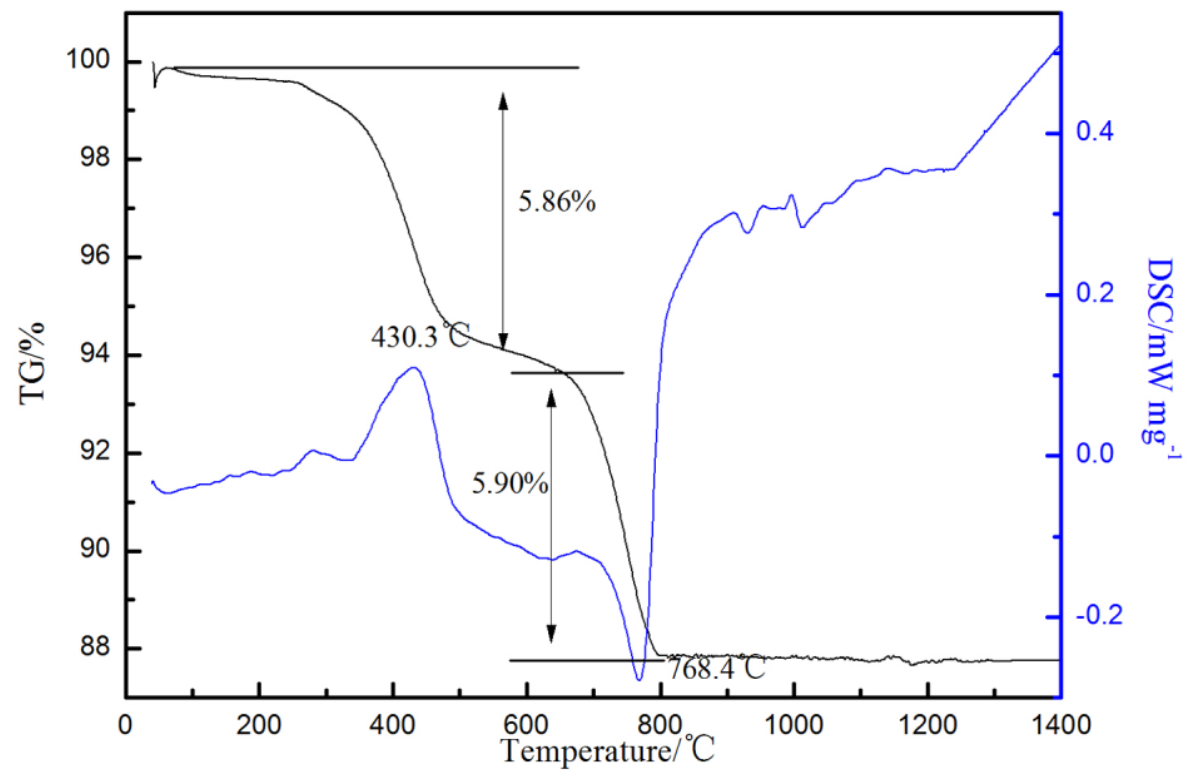

Fig. 1 TG and DSC curves of the specimen with $0.15 \mathrm{wt} \% \mathrm{NiO}$ 


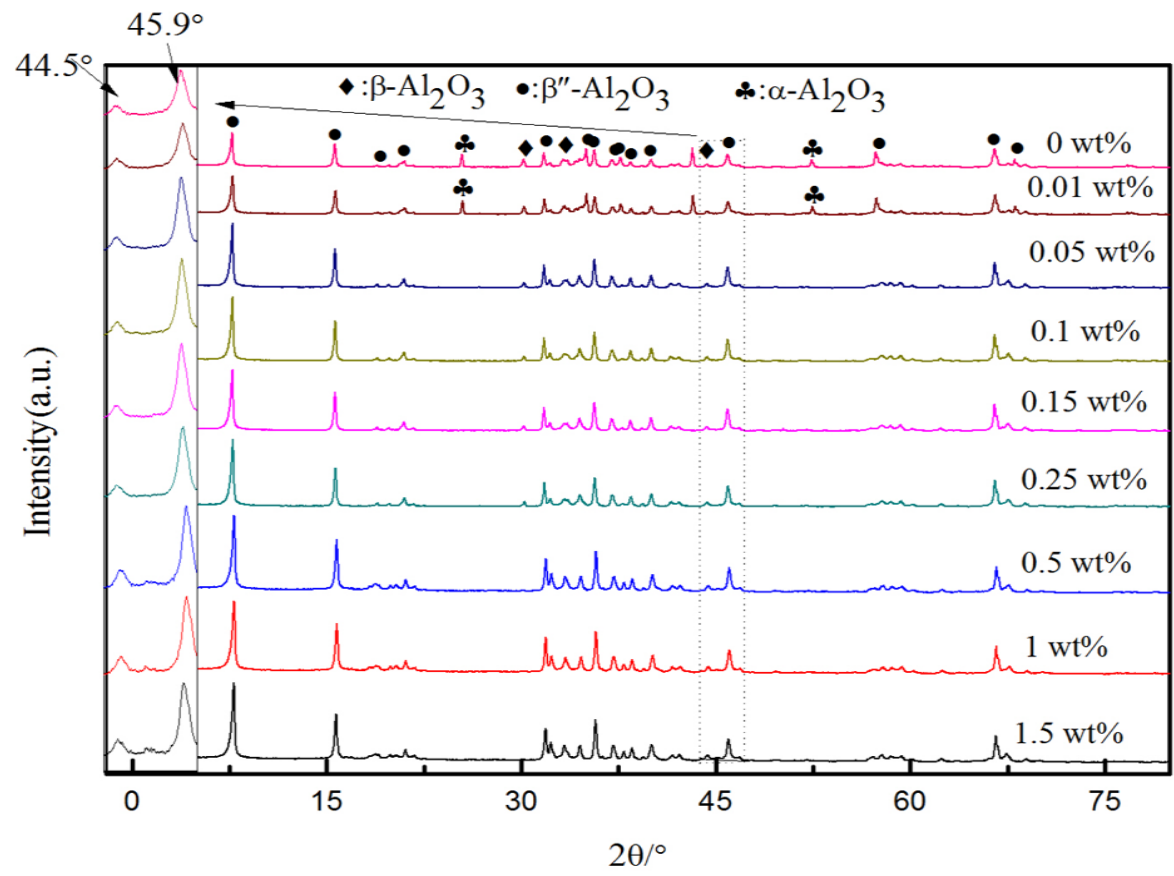

Fig.2 XRD spectra of precursor powders with different amounts of $\mathrm{NiO}$ doping 


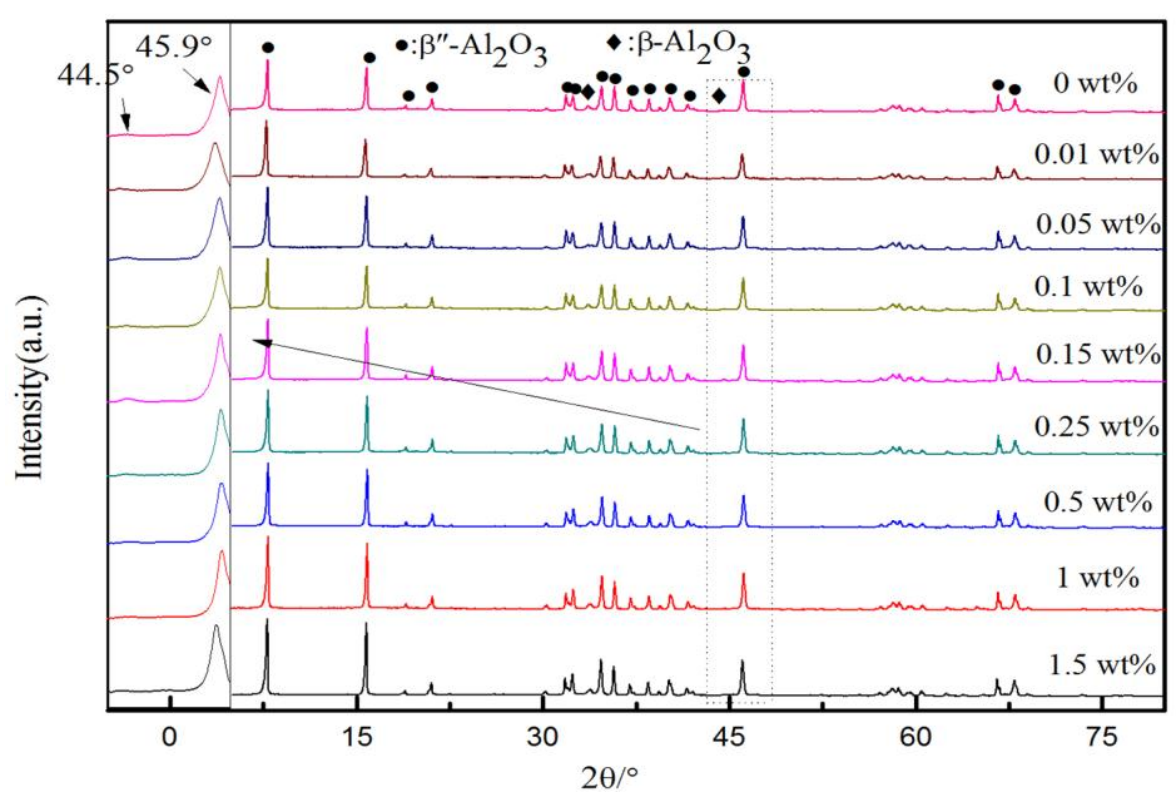

Fig. 3 XRD spectra of the sinters with different amounts of $\mathrm{NiO}$ doping 


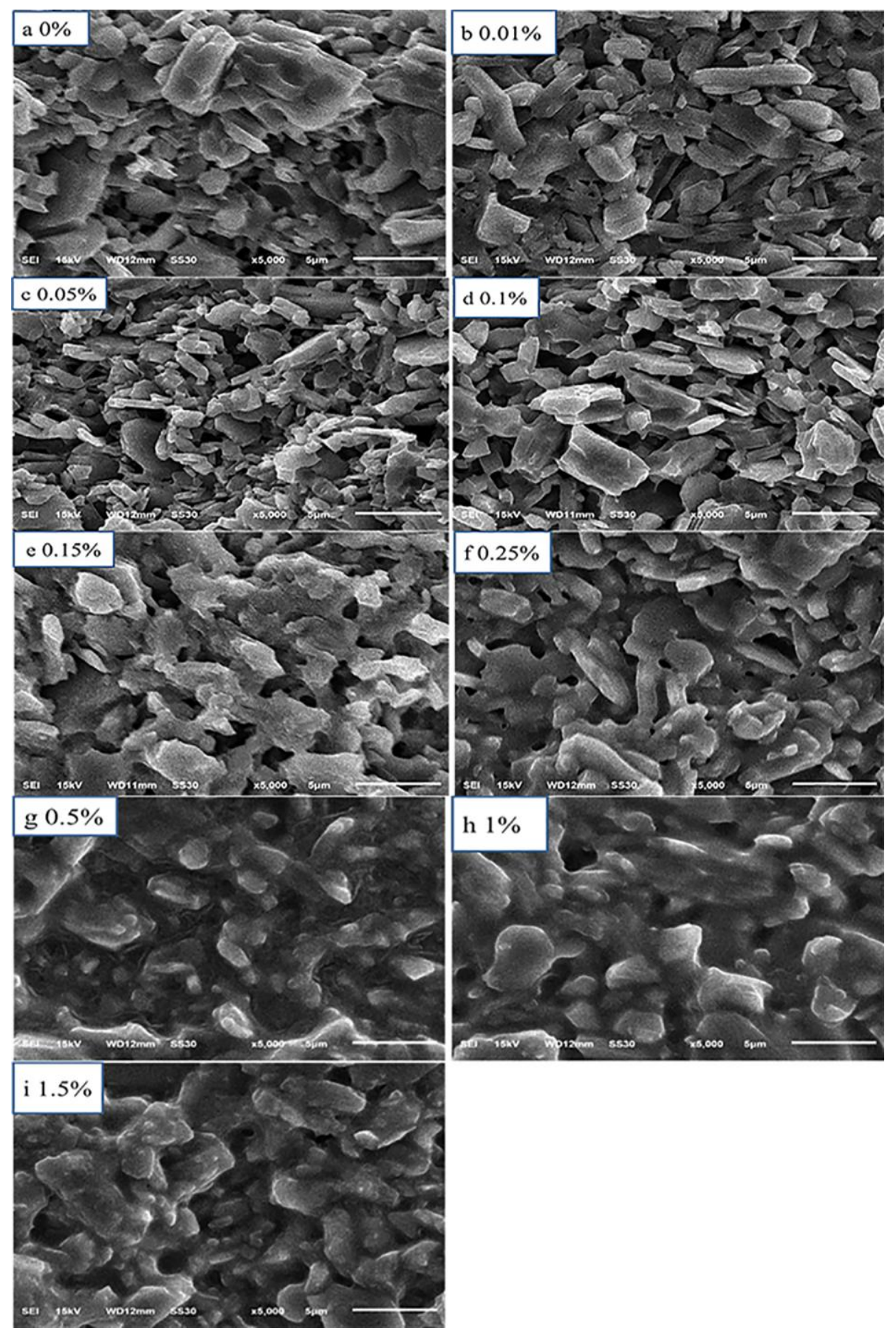

Fig.4 The cross section micrograph of the sinters with different amounts of $\mathrm{NiO}$ doping 


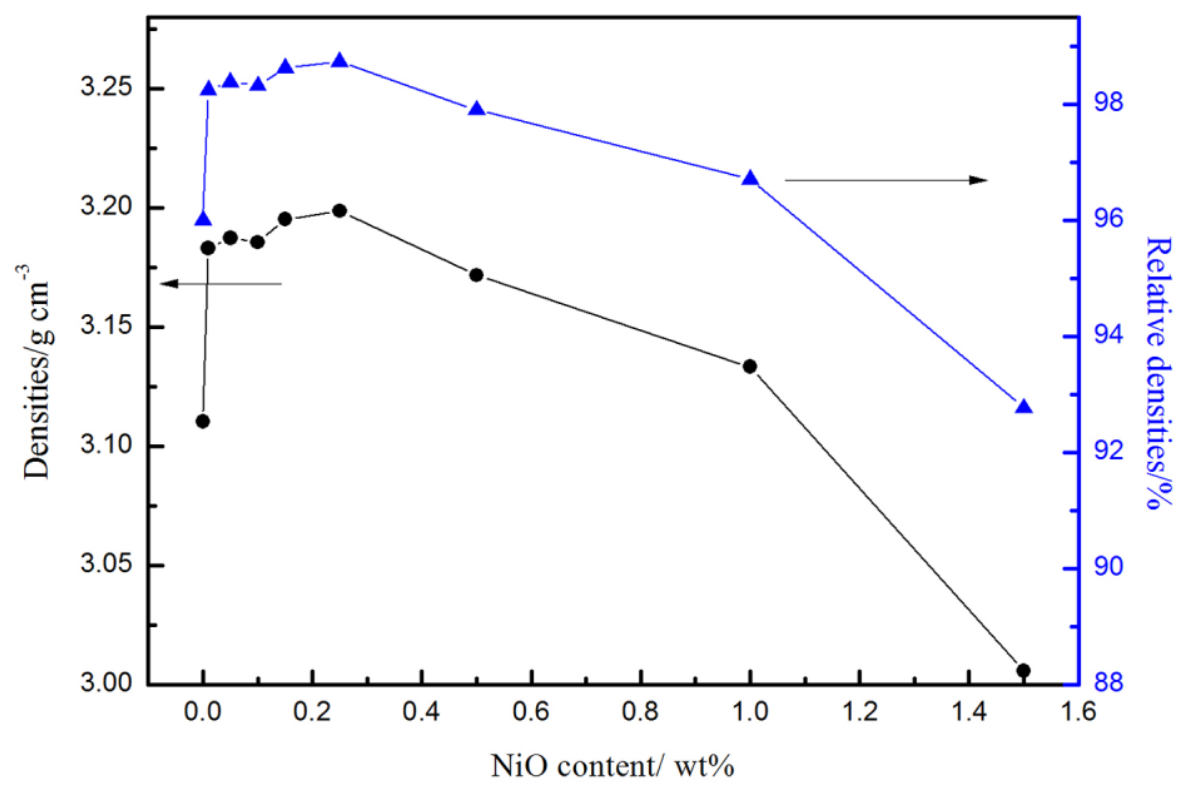

Fig.5 The measured and relative densities of the sinters with different amounts of $\mathrm{NiO}$ doping 


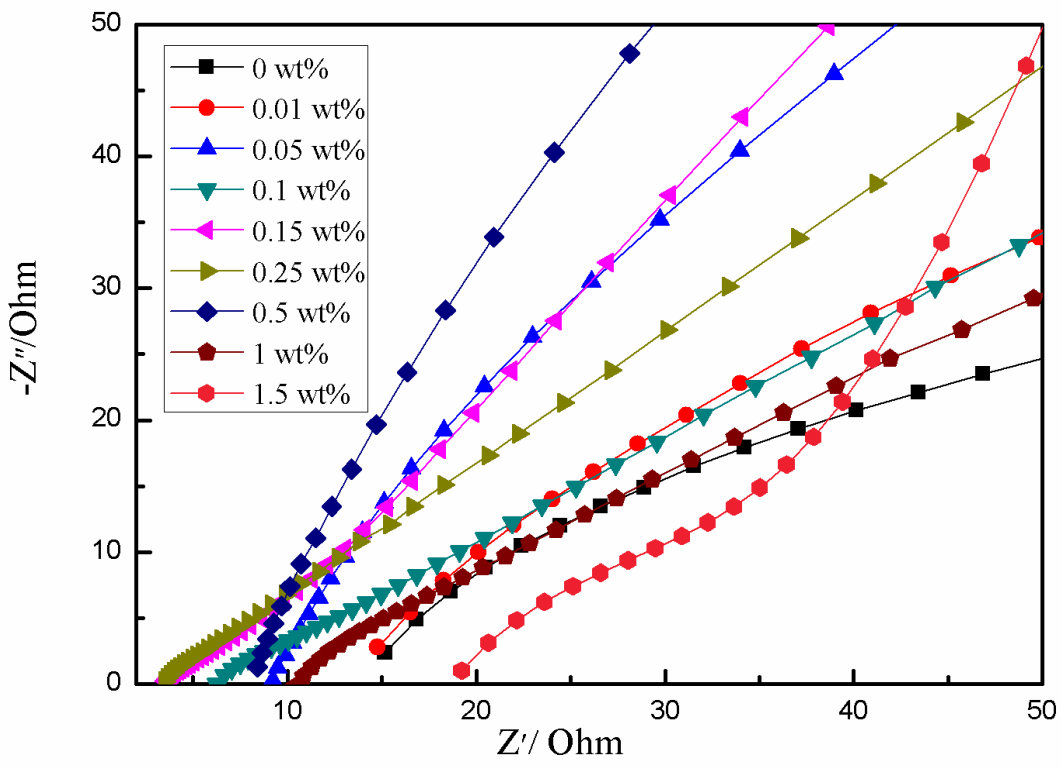

Fig.6 The impedance spectra of the sinters with different amounts of $\mathrm{NiO}$ doping at $350^{\circ} \mathrm{C}$ 


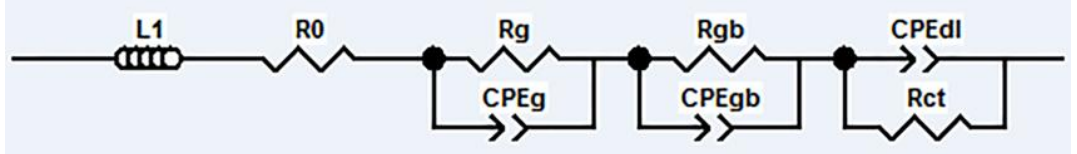

Fig.7 Equivalent circuits at different $\mathrm{NiO}$ contents

L1: Inductance due to platinum wire and silver electrode; R0: Lead wire resistance;

Rg: Grain resistance; CPEg: Grain capacitance; Rgb: Grain boundary resistance;

CPEgb: Grain boundary capacitance; CPEd1: a double layer capacitance;

Rct: Charge transition resistance 


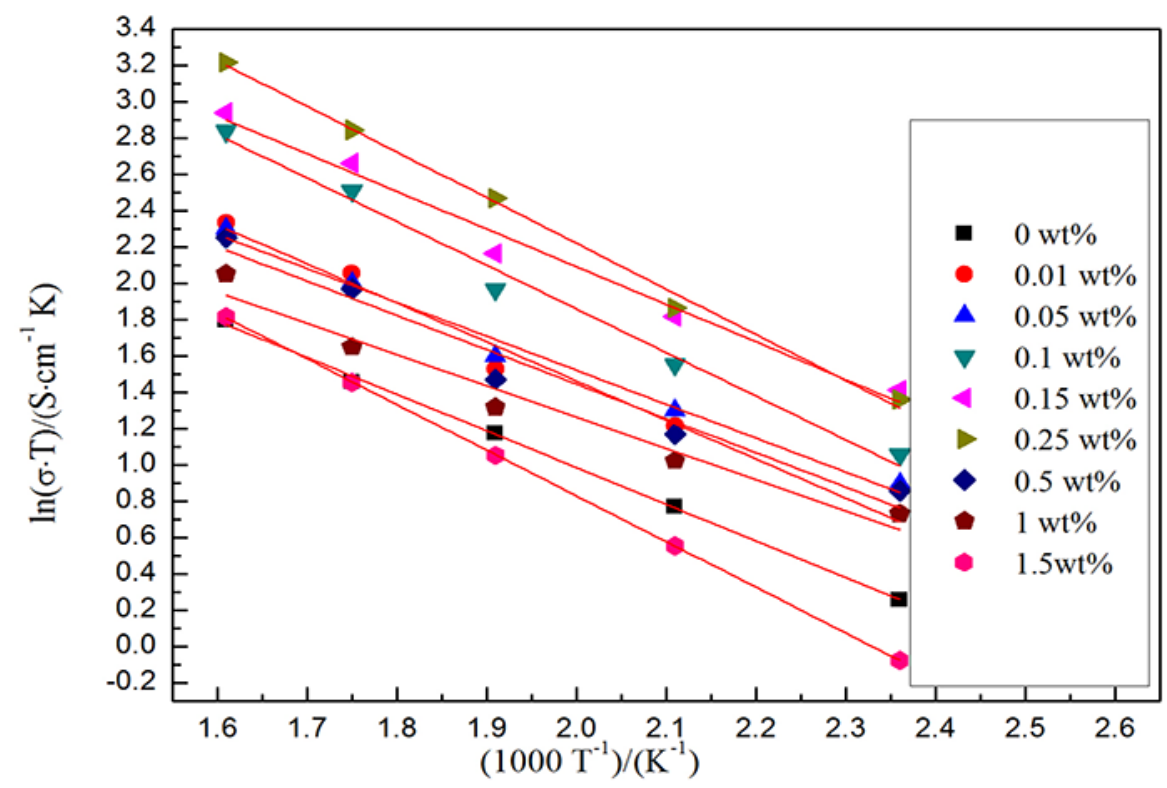

Fig.8 Arrhenius plot of resistivity data for the sinters with different amounts of $\mathrm{NiO}$ doping 
Table 1 The $\beta$ " phase content in precursor powders with different amounts of NiO doping

\begin{tabular}{cccccccccc}
\hline $\mathrm{NiO}$ wt\% & 0 & 0.01 & 0.05 & 0.1 & 0.15 & 0.25 & 0.5 & 1 & 1.5 \\
\hline $\begin{array}{c}\beta \text { " phase } \\
\text { content }(\%)\end{array}$ & 77.8 & 78.6 & 81.54 & 81.67 & 81.74 & 82.54 & 79.91 & 79.43 & 78.75 \\
\hline
\end{tabular}


Table 2 Some calculated parameters and measured properties of the sinters with different amounts of $\mathrm{NiO}$ doping

\begin{tabular}{|c|c|c|c|c|c|c|c|c|c|}
\hline $\mathrm{NiO}$ wt $\%$ & 0 & 0.01 & 0.05 & 0.1 & 0.15 & 0.25 & 0.5 & 1 & 1.5 \\
\hline $\begin{array}{c}\beta^{\prime \prime} \text { phase } \\
\text { content (\%) }\end{array}$ & 92.28 & 94.49 & 95.04 & 95.33 & 96.75 & 98.91 & 98.47 & 98.12 & 96.98 \\
\hline $\begin{array}{c}\text { Bending } \\
\text { strength(MPa) }\end{array}$ & 194 & 228 & 253 & 256 & 286 & 296 & 208 & 201 & 177 \\
\hline $\begin{array}{c}\sigma \text { at } 350^{\circ} \mathrm{C} \\
\left(\mathrm{S} \mathrm{cm}^{-1}\right)\end{array}$ & 0.015 & 0.018 & 0.024 & 0.035 & 0.038 & 0.066 & 0.029 & 0.023 & 0.012 \\
\hline $\mathrm{Ea}(\mathrm{eV})$ & 0.205 & 0.192 & 0.187 & 0.182 & 0.171 & 0.166 & 0.186 & 0.205 & 0.208 \\
\hline
\end{tabular}

